\title{
In situ hybridisation in herpetic lesions using a biotinylated DNA probe
}

\author{
M Dictor, E Renfjärd, A Brun
}

\begin{abstract}
In situ hybridisation was performed with a biotinylated DNA probe for herpes simplex virus (HSV) using high temperature denaturation on formalin fixed, paraffin wax sections of lung, brain, ganglion and keratinising and non-keratinising squamous epithelia. Eosinophilic viral nuclear inclusions or characteristically moulded multiple nuclei with altered chromatin, which were present in two cases of HSV encephalitis and one case of viral pneumonitis, all showed complete hybridisation visualised by an alkaline phosphatase/nitroblue tetrazolium detector system. HSV encephalitis and trigeminal ganglionitis, which were confirmed serologically or clinicopathologically but lacked nuclear changes, also gave positive dense nuclear signal in neurons, glias and satellite cells. No staining was present in the ganglion cells in trigeminal zoster, the glia in progressive multifocal leucoencephalopathy, or in a variety of cells in a lung coinfected with cytomegalovirus. In 10 herpetic blisters of squamous epithelia, infected cells hybridised strongly, while morphologically similar herpes zoster lesions remained negative. In neural tissues non-hybridisation staining was most obtrusive in corpora amylacea and seemed to reflect nonspecific probe adherence. In squamous epithelium, major non-hybridisation staining was caused by probe and antibody possibly adhering to intracellular keratin.
\end{abstract}

The HSV probe permits specific detection of virus in the absence of characteristic nuclear changes and allows varicella zoster virus to be differentiated from HSV, provided that the aforementioned problems with non-hybridisation staining are borne in mind.

Several reviews of in situ hybridisation using biotinylated nucleic acids have recently been published which critically describe the use $\mathrm{s}^{1-4}$ and interpretation ${ }^{5}$ of such probes in the study of pathological specimens routinely processed to paraffin wax. In the absence of confirmative virus isolation, in particular, in situ hybridisation using biotinylated probes should be able to identify with high specificity infected cells lacking pathognomonic inclusions or at least be able to confirm the nature of inclusions which are equivocal, as claimed by some authors. ${ }^{6}$
In this study we used a commercially available biotinylated DNA viral probe to confirm the presence of herpes simplex type I/II (HSV) in herpetic lesions from lung, brain, ganglion and squamous epithelia. A modification of a widely used protocol was used which requires a high denaturing temperature to optimise target hybridisation. ${ }^{1}$ Cases were selected to detect virus both in the presence and absence of inclusion bodies. The ability of the HSV probe to distinguish specifically morphologically identical herpetic nuclear changes in squamous epithelium (HSV $v$ varicella/herpes zoster virus, $\mathrm{HVZ}$ ) was also studied. We also addressed the problem of non-hybridisation staining, which may lead to errors in interpretation.

\section{Methods}

Tissue specimens were fixed in $10 \%$ neutral formalin for several hours (skin specimens), up to several days (most necropsy specimens), or at least two weeks (whole brains). One case with pulmonary cytomegalovirus (CMV) and $\mathrm{HSV}$ was fixed for six hours in paraformaldehydelysine-periodate (PLP). ${ }^{7}$ Cases were divided into two main groups (table 1): group A, which showed characteristic nuclear changes in haematoxylin and eosin tissue sections (three cases) indicating HSV, ${ }^{8}$ and group $\mathrm{B}$, which lacked inclusions (three cases) but which had serological or clinical signs indicating specific infection. We then applied probe for HSV to the appropriate sections to determine sensitivity relative to the number of virally altered cells in group A. Sensitivity was judged in group A on the basis of whether more, fewer, or the same number of nuclei with inclusions hybridised in the same counterstained section. In group $\mathrm{B}$, sensitivity was either positive or negative relative to laboratory test results or clinical diagnosis. In a separate squamous epithelial group, one case each of HSV stomatitis and vulvitis showing herpetic giant cells with characteristically moulded multiple nuclei were hybridised, and 10 cutaneous herpetic infections with similar changes, clinically typical of varicella/zoster (two cases confirmed by serology, all zoster cases with typical dermatomal distribution), served as specificity controls (table 2).

The following controls were used: (1) for probe specificity, paraffin wax sections of formalin-fixed cultured fibroblasts infected with CMV and cytospin preparations of cultured monkey kidney cells infected with $\mathrm{HSV}$ of either type 1 or 2 and briefly fixed in cold $10 \%$ formalin; (2) sections of the tissue with HSV inclusions were run in parallel with test sec- 
Table 1 In situ hybridisation of biotinylated HSV DNA probe in histological sections of tissue $(A)$ showing characteristic nuclear changes and $(B)$ with histologically normal nuclei but with positive serology (specific IgG and IgM titres), culture, or characteristic clinicopathological features

\begin{tabular}{|c|c|c|c|c|}
\hline Case No & Tissue & $\begin{array}{l}\text { Estimated } \\
\text { fixation } \\
\text { time }\end{array}$ & $\begin{array}{l}\text { Clinico- } \\
\text { pathological } \\
\text { features }\end{array}$ & $\begin{array}{l}\text { Relative } \\
\text { sensitivity }\end{array}$ \\
\hline$\underset{1}{\text { Group } A:}$ & Lung & 6 hours, PLP & $\begin{array}{l}25 \text { year old woman; } \\
\text { Hodgkin's disease, CMV } \\
\text { HSV pneumonitis }\end{array}$ & $>$ \\
\hline 2 & Brain (biopsy) & $\begin{array}{l}>24 \text { hours, } 10^{\circ}{ }^{\circ} \\
\text { neutral formalin }\end{array}$ & $\begin{array}{l}41 \text { year old man; HSV } \\
\text { encephalitis }\end{array}$ & $>$ \\
\hline $3 \dagger$ & Brain & $\begin{array}{l}14 \text { days, } 10^{\circ} \text { o neutral } \\
\text { formalin }\end{array}$ & $\begin{array}{l}8 \text { month old female; } \\
\text { necrotising encephalitis }\end{array}$ & $=$ \\
\hline $\begin{array}{l}\text { Group B: } \\
4\end{array}$ & $\begin{array}{l}\text { Trigeminal } \\
\text { ganglion }\end{array}$ & $\begin{array}{l}>24 \text { hours, } 10^{\circ}{ }^{\circ} \\
\text { neutral formalin }\end{array}$ & $\begin{array}{l}68 \text { year old woman; zoster } \\
\text { ophthalmicus (HVZ), } \\
\text { ganglionitis, subarachnoid } \\
\text { haemorrhage }\end{array}$ & - \\
\hline $5 \dagger$ & $\begin{array}{l}\text { Trigeminal } \\
\text { ganglion }\end{array}$ & $\begin{array}{l}>24 \text { hours, } 10^{\circ} \\
\text { neutral formalin }\end{array}$ & $\begin{array}{l}55 \text { year old man; } \\
\text { necrotising HSV } \\
\text { encephalitis }\end{array}$ & ++ \\
\hline $6+$ & Whole brain & $\begin{array}{l}14 \text { days, } 10^{\circ}{ }_{0} \text { neutral } \\
\text { formalin }\end{array}$ & $\begin{array}{l}81 \text { year old woman; HSV } \\
\text { encephalitis with left } \\
\text { temporal lobe necrosis }\end{array}$ & +++ \\
\hline
\end{tabular}

$\star>$ number of positive cells exceed those with unequivocal inclusions.

$=$ positive cells all with inclusions; - no reaction; + to +++ relative number of infected cells tpositive cerebrospinal fluid serology:

Case 3-serum HSV:IgG titre from 60 to 360 in six days, HSV isolated from brain and shown to be type I.

Case 5-cerebrospinal fluid:serum HSV:IgG titre ratio increased to 0.8 and after four month interval 0.9 .

Case $6-\mathrm{HSV}: \mathrm{IgM}$ positive at 300 ; HSV:IgG cerebrospinal fluid serum titre ratio increased to 1.5 and after eight days to $2 \cdot 1$.

tions (table 2) as a positive control; (3) hybridisation mixture without probe was applied to adjacent sections and processed in parallel with test sections as a negative control; (4) viral probes irrelevant to the section under study (CMV and JC virus, JCV) provided specificity controls for the test sections; and (5) $\mathrm{HSV}$ probe applied to six cases of progressive multifocal leucoencephalopathy, a demyelinating viral inclusion disease of brain caused by $\mathrm{JCV}$, served as a further probe specificity control.

A commercially available (Enzo) HSV probe, labelled with bio-11-dUTP, consisted of fragment lengths of $200-2000$ base pairs derived from clones of the plasmid pBR322 containing two cloned viral genomic segments of 8.0 and 16.0 kilobase pairs which had been inserted in the $\mathrm{BamHl}$ site of the vector. Biotinylated probes for CMV and JCV (Enzo) were similarly produced, and all probes were freed of vector sequences by restriction enzyme treatment and electrophoretic gel purification. A probe concentration of $0.5 \mu \mathrm{g} / \mathrm{ml}$ was used.

The method of Unger et al was used with several modifications for hybridisation protocol (table 3). Loosening of sections on slides coated with poly-D-lysine was prevented by

Table 2 HSV probe applied to epithelial biopsy specimens of classic $H S V$ and $H V Z$ bullae (fixation in most cases $<24$ hours in $10 \%$ formalin)

\begin{tabular}{lll}
\hline Case No & $\begin{array}{l}\text { Clinicopathological } \\
\text { diagnosis }\end{array}$ & $\begin{array}{l}\text { Hybridisation } \\
\text { results }\end{array}$ \\
\hline 7 & HSV stomatitis & +++ \\
8 & HSV vulvitis & +++ \\
9,10 & Zoster & - \\
$11-17^{\star}$ & Zoster & -
\end{tabular}

*Positive serum HVZ titre.

† Age range 20-80 years, two men and six women, grouped vesicles in all seven cases of zoster and diffuse rash in one case of varicella in a 20 year old man; two patients immunosuppressed before rash. immunosuppressed before rash.

$+t+$ relative number of infected cells; - no reaction. switching to 3-aminopropyl-triethoxysilane (Sigma), ${ }^{9}$ a covalently binding adhesive applied at a concentration of $2^{\circ}$ in acetone.

In an attempt to increase the intensity of hybrid formation by increasing target accessibility, we added a predigestion step of $0.2 \mathrm{~N}$ $\mathrm{HCl}$ for 15-25 minutes and also tried different proteases (proteinase $\mathrm{K}$ [Sigma], $100 \mu \mathrm{g} / \mathrm{ml}$ for 30 minutes, or $0.4 \%$ pepsin in $10 \mathrm{mM} \mathrm{HCl}$ for one hour at $\left.37^{\circ} \mathrm{C}\right) .{ }^{10}$

Sources of non-hybridisation staining which detracted from the specificity of the technique were determined by sequential omissions in the procedure. Attempts were made to reduce such staining by subjecting sections treated with proteinase to $5 \mathrm{ml}$ acetic anhydride in $100 \mathrm{ml}$ triethanolamine $(\mathrm{pH} 8.0)$ before hybridisation. ${ }^{11}$

\section{Results}

Hybridisation results were reproducible when several runs were made. Positive hybridisation produced a dark, coarsely granular blue-brown reaction product. This was sharply localised to the nucleus unless cell lysis had occurred during the pathological process. All controls stained appropriately.

Lung tissue from case 1, containing numerous CMV inclusions, showed a few scattered cells with multiple nuclei and washed-out chromatin suggestive of a herpetic coinfection. Hybridisation yielded a surprisingly large number of strongly reactive nuclei throughout the section.

Case 2, with herpes encephalitis, showed only one eosinophilic inclusion in a stained section, while four hybridising cells were detected in an adjacent section. In case 3 with pronounced HSV inclusion body encephalitis, all inclusions hybridised with a strong sharply localised signal in neurons and glia (fig 1).

\section{Table 3 Hybridisation protocol based on Unger et al ${ }^{12}$}

1 Dewaxing in xylene and dehydration in $95^{\circ}$ ethanol Enzymatic predigestion with nuclease-free pronase

$0.3 \mathrm{mg} / \mathrm{ml}$ in $0.05 \mathrm{M}$ TRIS- $\mathrm{HCl}$ with $5 \mathrm{mM}$ EDTA (pH 7.4), 15 minutes at $37^{\circ} \mathrm{C}$, then two washes in glycine, $2 \mathrm{mg} / \mathrm{ml}, 0 \cdot 1 \mathrm{M} \mathrm{NaCl}$ and $0 \cdot 1 \mathrm{M}$ TRIS- $\mathrm{HCl}$, $\mathrm{pH} 7.5$

3 Probe cocktail $(0.5 \mu \mathrm{g} / \mathrm{ml}$ probe $+1 \times$ Denhardt's solution $+25 \mathrm{mM}$ sodium phosphate $+250 \mu \mathrm{g} / \mathrm{ml}$ solution $+25 \mathrm{mM}$ sodium phosphate $+250 \mu \mathrm{g} / \mathrm{ml}$ SSC. Solution heated to $90^{\circ} \mathrm{C}$, then cooled rapidly to $0^{\circ} \mathrm{C} ; \star 20 \mu \mathrm{l}$ applied to section and covered with $0^{\circ} \mathrm{C} ; \star 20 \mu \mathrm{l}$ applied
polypropylene slip

4 Denaturation in warm air oven ${ }^{\star}$ at $100^{\circ} \mathrm{C}$ for 10 minutes

Hybridisation at $37^{\circ} \mathrm{C}$ for two hour

Washes in $2 \times, 0.2 \times$, and $0.16 \times$ SSC for three minutes each

$3^{\circ}{ }_{0}$ BSA in $0 \cdot 1 \mathrm{M}$ TRIS- $\mathrm{HCl}(\mathrm{pH} 7 \cdot 5)$, for five minutes, then 20 minutes ${ }^{\star}$ in $10^{\circ}{ }_{0}$, normal serum diluted in $2 \times$ SSC

$8^{\star} \quad$ Amplification with goat antibiotin AB 1:5000 overnight at $4^{\circ} \mathrm{C}$, then biotinylated rabbit antigoat overnight at $4^{\circ} \mathrm{C}$, then
$1: 200$ one hour at $37^{\circ} \mathrm{C}$

$1: 200$ one hour at $37^{\circ} \mathrm{C}$
Three washes in TRIS (pH 7.5)

9 Three washes in TRIS (pH 7.5) 30 minutes in avidin-alkaline phosphat
(Dako) diluted $1 / 300$ in normal serum Three minute wash in $0.1 \mathrm{M}$ TRIS- $\mathrm{HCl}(\mathrm{pH} \mathrm{7.5)} 0 \cdot 1$ $\mathrm{N} \mathrm{NaCl}, 5 \mathrm{mM} \mathrm{MgCl}, 1{ }^{\circ}{ }_{0} \mathrm{BSA}$, and $0.01^{\circ}{ }_{\circ}$ triton $\mathrm{X}$ 100; repeat with first three ingredients after changing $\mathrm{pH}$ to 9.5 and $\mathrm{MgCl}_{2}$ to $50 \mathrm{mM}$

Slides up to two hours at $37^{\circ} \mathrm{C}$ in fresh solution of 0.1 $\mathrm{ml}$ of $50 \mathrm{mg} / \mathrm{ml} 5$-bromo-4-chloro-3-indoyl phosphate in $100^{\circ}$ o dimethylformamide $+0.2 \mathrm{ml}$ of nitroblue tetrazolium chloride, $50 \mathrm{mg} / \mathrm{ml}$ in $50^{\circ}{ }_{0} \mathrm{DMF}$, both added to $30 \mathrm{ml}$ TRIS buffered saline ( $\mathrm{pH} \mathrm{9.5)}$

13 Wash in distilled water, counterstain, with metani yellow, and mount

* Modifications to method. 
Figure 1 Confirmatory hybridisation with $H S V$ probe in herpes encephalitis with widespread nuclear inclusions.
Figure 2 Densely stippled HSV signal in nuclei of trigeminal ganglion cells associated with herpes encephalitis. Note also staining of satellite cell nuclei (arrow). Lipofuscin granules are seen in a ganglion cell in the upper left corner.

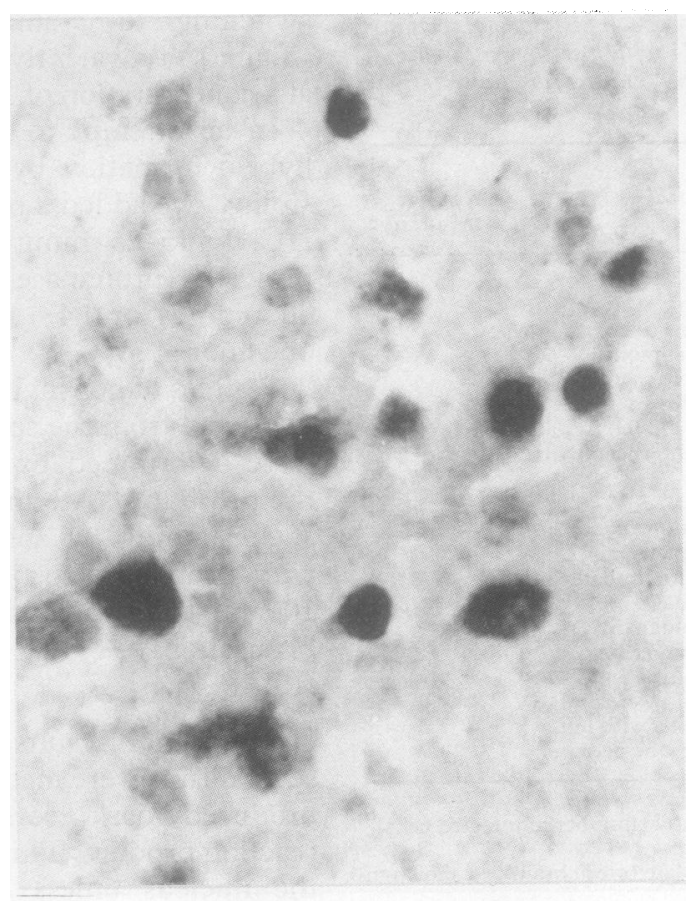

Relatively clean background was achieved in the lipid rich brain, whereas fibrous components displayed varying degrees of finely granular or dusky coloration. Erythrocyte membranes were often heavily coloured by the detector reagents rather than by probes. Background was not reduced by previous treatment with acetic anhydride.

In group $\mathrm{B}$, the trigeminal ganglion removed at necropsy (case 5) with resolving herpes simplex encephalitis contained a mild lymphocytic infiltrate. The HSV probe hybridised with about one third of the nuclei of ganglion cells and surrounding satellite cells (fig 2), while no hybridisation was noted in the nerve cell body. Case 4 , with zoster ophthalmicus and trigeminal mononuclear cell infiltrates, showed no reaction with HSV or CMV probes. Nonhybridisation staining was minimal and confined to collagenous structures.

Both cases 7 and 8, with mucosal herpes

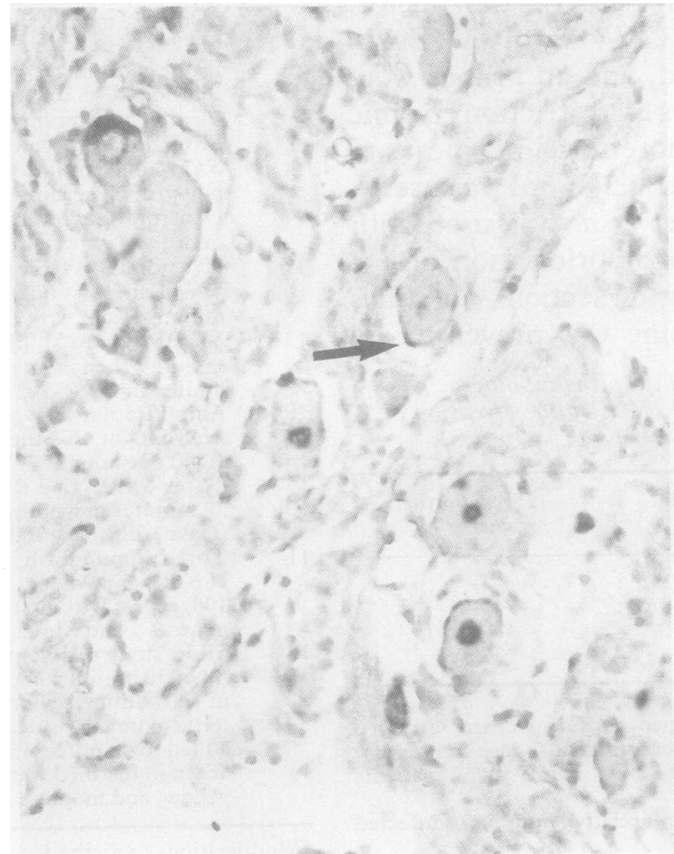

simplex, produced strong specific nuclear hybridisation in the infected blister cells (fig 3a). None of the $10 \mathrm{HVZ}$ sections hybridised convincingly (fig $3 \mathrm{~b}$ ), although interpretation was sometimes made difficult by non-hybridisation cytoplasmic staining in keratinocytes adjoining the viral bullae and in follicular epithelium. Occasional ring-like staining of degenerated cells containing characteristic nuclear alterations was evident in $\mathrm{HVZ}$, but true hybridisation was conspicuously absent from the nuclei. Addition of RNAse (100 $\mathrm{mcg} / \mathrm{ml}$ for 30 minutes at $37^{\circ} \mathrm{C}$ ) after step 2 in table 3 did not decrease background staining, which was diminished but not abolished in controls without probe.

No difference was found in the intensity of staining in positive cases predigested with one or the other of the proteinases, in contrast to the experience of others who found pepsin digestion to be superior, ${ }^{10}$ and no case gave a positive result with an irrelevant probe.

\section{Discussion}

Sensitivity in terms of the number of cells with diagnostic viral inclusions which hybridise was $100 \%$ for HSV in all five cases studied. The probe we used also specifically identified productive viral infection in the absence of pathognomonic histological signs of the disease in both group B cases with HSV related disease. Although formalin is not usually considered to be the optimal fixative for in situ hybridisation detection of DNA due to crosslinking of proteins to nucleic acid, the signal is nevertheless obtainable in tissues with numerous viral inclusions subjected to pro-

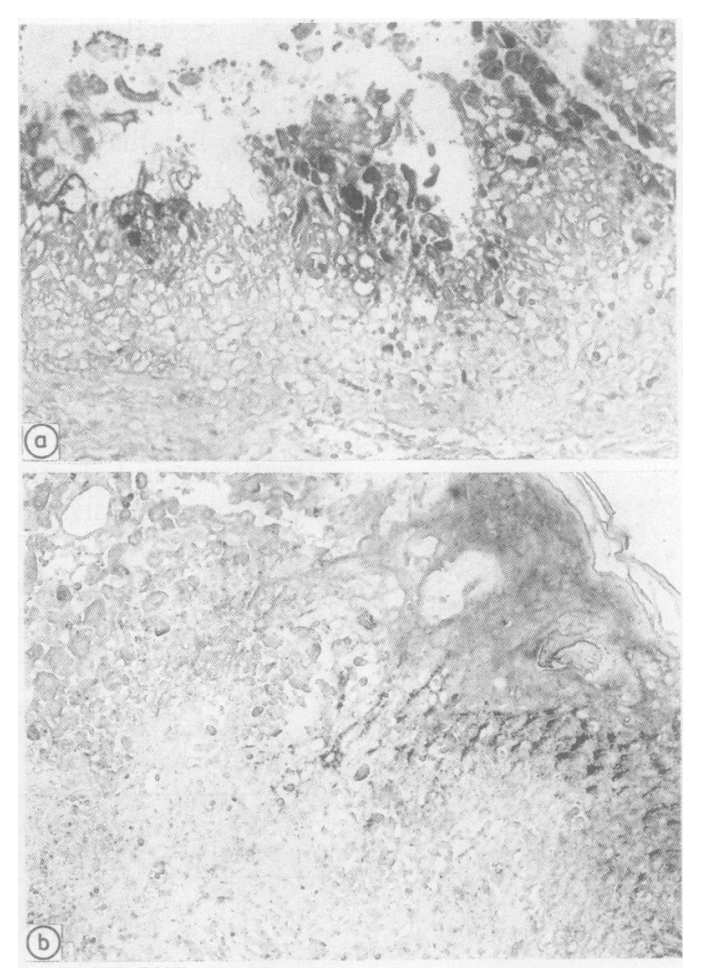

Figure 3 (a) All nuclei with herpetic changes in gingival biopsy specimen show strong hybridisation with HSV probe; moderate non-hybridisation background staining. (b) Negative reaction in cutaneous zoster control. Note non-hybridisation cytoplasmic staining in keratinocytes which flank the blister and slight perinuclear background in degenerating blister cells. 
longed fixation as was evidenced by strong reactivity for $\mathrm{HSV}$ in brains fixed for at least two weeks in this study. Generally, several hundred virus copies in a cell are needed before biotinylated probes give a visible reaction, and it has been shown that viral culture remains more sensitive than in situ hybridisation. ${ }^{5}$

The frequent absence of HSV inclusions in cases of suspected HSV encephalitis suggests that in situ hybridisation could be a useful tool in confirming infection, especially if the sensitivity and specificity could be shown to surpass that of immunohistochemical detection methods using virus isolation as the standard $\left(70^{\circ}{ }_{0}\right.$ true $v 9^{\circ}{ }_{0}$ false positive results in one large series). ${ }^{12}$ Interestingly, the results in the case of trigeminal HSV ganglionitis indicate that active viral replication occurs not only in nuclei of neurons but also in nuclei of their supporting satellite cells, as shown experimentally in mice. ${ }^{13}$

A strong signal was achieved in HSV giant cells in mucosal herpes simplex vesicles, whereas zoster cases remained negative. These results suggest that in situ hybridisation might be applied to cases in which clinical differentiation of HSV from HVZ is difficult, and further trials, perhaps using serotype specific probes, may show whether the method is superior to immunofluorescence on smears of blister material.

Specificity of hybridisation reactions in tissue sections requires the definitive presence of granular compact product and its differentiation from opaque, sharply contoured colour precipitates and non-hybridisation staining, often due to endogenous biotin. A minimal amount of finely stippled signal product was produced in some nuclei when suitable probe was applied, but in our experience this effect can be seen even with irrelevant probes and this would by itself be considered insufficient for a positive interpretation.

Background reactions in squamous epithelia were not dependent on predigestion or denaturation, and sequential omission of steps in the protocol incriminated both biotinylated probe and antibiotin antibody (monoclonal as well as polyclonal) as ultimate sources that would be more important than endogenous biotin. As non-keratinising mucosal epithelium did not show a similar degree of background, it is possible that DNA adheres to intracellular keratin, a well recognised phenomenon in regard to antibodies.

Increased background staining due to endogenous biotin in tissues such as liver and kidney has been noted, ${ }^{4}$ which makes correct interpretation of cytoplasmic staining essential. Sections of spuriously stained cytoplasms, as may occur in acantholytic blister cells, for example, can be misleading unless appropriate localisation of solid hybridisation staining in all pathologically altered cells is demanded. True cytoplasmic hybridisation is not likely to be a problem with HSV when biotinylated DNA probes are used because intact cells contain too few cytoplasmic viral particles for detection. Viral mRNA may be detectable in latently infected cell bodies of trigeminal ganglion, which has been reported for a radioactive HSV probe,${ }^{14}$ but it remains to be shown whether the double stranded probe and hybridisation conditions we used would allow mRNA to be detected in latent infection. RNAse pretreatment of skin sections did not, in any case, decrease the cytoplasmic background flanking the viral blisters.

We agree with Myerson, ${ }^{5}$ who found that corpora amylacea of the brain often produced spurious staining. This could generally be distinguished from true hybridisation by its typical location, and confirmed by examining adjacent sections stained preferably with periodic acid Schiff. This type of staining could also be related to non-specific probe adherence, but we noted that it could affect only one out of several slides run simultaneously but with different probes.

In summary, the findings of this study indicate that the diagnosis of herpes simplex infection may be expedited by hybridisation using biotinylated DNA in a protocol requiring one working day compared with several days for virus isolation. Careful attention must be paid to avoiding the pitfalls in interpretation due to non-specific staining.

This work was supported by John och Augusta Perssons stiftelse för vetenskaplig medicinsk forskning, the Royal Physiographical Society of Lund, and the Medical Faculty of the University of Society
Lund.

1 Unger ER, Budgeon LR, Myerson D, Brigati DJ. Viral diagnosis by in situ hybridization. Description of a rapid diagnosis by in situ hybridization. Description of a rapid simplified

2 Löning T, Milde K, Foss HD. In situ hybridization for the detection of cytomegalovirus (CMV) infection. Application of biotinylated CMV-DNA probes on paraffin specimens. Virchows Arch (Pathol Anat) 1986; 409:777-90.

3 Pringle JH, Homer CE, Warford A, Kendall CH, Lauder I. In situ hybridization: alkaline phosphatase visualization of biotinylated probes in cryostat and paraffin sections. Histochem J 1987;19:488-96.

4 Warford A. In situ hybridization: a new tool in pathology. Med Lab Sci 1988;45:381-94.

5 Myerson D. In situ hybridization. In: Colvin RB, Bhan AT, McCluskey RT, eds. Diagnostic Immunopathology. New York: Raven Press, 1988:475-98.

6 Masih AS, Linder J, Shaw BW, et al. Rapid identification of cytomegalovirus in liver allograft biopsies by in situ hybridization. Am J Surg Pathol 1988;12:362-7.

7 McLean IW, Nakane PK. Periodate-lysine-paraformaldehyde fixative. A new fixative for immunoelectron microscopy. J Histochem Cytochem 1974;22:1077-83.

8 Wills EJ. Ultrathin section electron microscopy in the diagnosis of viral infections. In: Sommers SC, Rosen PP, eds. Pathology Annual. Vol. 18. Part 1. Norwalk: Appleton eds. Pathology Annual. Vol. 18.

9 Maples JA. A method for the covalent attachment of cells to glass slides for use in immunohistochemical assays. $A m J$ glass slides for use in immun
Clin Pathol 1985;83:356-63.

10 Burns J, Redfern DRM, Esiri MM, McGee JO'D. Human and viral gene detection in routine paraffin embedded tissue by in situ hybridisation with biotinylated probes: viral localisation in herpes encephalitis. J Clin Pathol 1986;39:1066-73.

11 Haase AT. Analysis of viral infections by in situ hybridisation. In: Valentino KL, Eberwine JH, Barchas JD, eds. In tion. In: Valentino KL, Eberwine JH, Barchas JD, eds. In situ hybridization-application to neurobiolog
Oxford University Press, 1987:197-219.

12 Nahmias AJ, WHitley RJ, Visintine AN, Takei Y, Alford $\mathrm{CA}$, and The Collaborative Antiviral Study Group. CA, and The Collaborative Antiviral Study Group. and their diagnostic significance. J Infect Dis 1982;145: and their

13 Stroop WG, Rock DR, Fraser NW. Localization of herpes simplex virus in the trigeminal and olfactory systems of the mouse central nervous system during acute and latent infections by in situ hybridization. Lab Invest 1984;51: $27-38$

4 Galloway D, Fenoglio C, Shevchuk M, McDougall JK. Detection of herpes simplex RNA in human sensory ganglia. Virology 1979;95:265-8. 